\title{
THE "KINGDOM OF GOD ON EARTH" AND EARLY CHICAGO PRAGMATISM
}

\author{
Daniel Tröhler \\ Pestalozzianum Research Institute for the History of Education \\ Teachers College, Zurich
}

\begin{abstract}
Pragmatism has been rediscovered in recent years and presented as emblematic of modern thinking. At the center of this worldwide interest in late-nineteenth century Pragmatism stood, first, a rejection of the traditional dualistic construction of the world in philosophy and psychology; second, a distinguishing of the findings of learning theory from those of evolutionary theory; and, third, a consideration of industrial democracy as the context of modern thinking and action. In this essay Daniel Tröhler shows that these innovations were far less secular than has generally been assumed. Underlying early Chicago Pragmatism is a reformed (Calvinist) Protestant mentality that was shaped by a vision of a common mission: realizing the "kingdom of God on earth" - a mentality that responded critically to the provocations of modernity (specifically, industrialization and capitalism) and, through this response, developed a distinctive discourse that came to be called "Pragmatism."
\end{abstract}

\section{REFORMEd CONGREgATION}

In the last quarter of the nineteenth century, many young American college graduates traveled to Germany to obtain their doctoral degrees. These journeys took place in the context of changes occurring in the traditional American system of higher education during this period. Previously, the colleges were not so much research institutions as theological seminaries aimed primarily at educating future pastors; for this reason, doctorates were rare. However, with the rise of new, modern research universities, such as Johns Hopkins University in Baltimore, established in 1876, there was a need for qualified faculty. Many young college graduates therefore traveled to Germany in order to acquire the $\mathrm{PhD}$ degrees that would qualify them for teaching positions in the research departments of these new universities - and also of older universities, such as Princeton or Harvard, which were being reformed more slowly. ${ }^{1}$

At first glance, the careers of these young graduates seem to follow a straightforward plan - go to Germany, earn a doctorate, and then embark on an academic career in the United States. This has often led people to conclude that the American university system was more or less a copy of the German system. But upon closer examination, the differences between the systems were much greater than the traditional account would have us believe. The greatest difference no doubt emerged from the different way that the universities saw themselves in relation to religion, which led to numerous other differences. To illustrate, take the example of James Hayden Tufts, ${ }^{2}$

1. Laurence R. Vesey, The Emergence of the American University (Chicago: University of Chicago Press, 1965), $174 \mathrm{ff}$.

2. James Hayden Tufts was born on July 9, 1862 in Monson, Massachusetts, and was taught by his father at Monson Academy. After graduating from Amherst College in 1884, he served as high school principal in Westport, Connecticut, for one year and then taught mathematics at Amherst College for two years. From 1887 to 1889 , he studied at Yale Divinity School under William Rainey Harper, who would later become president of the University of Chicago. 
who studied Kant in Berlin and Freiburg in 1891 and completed a doctorate on Kant's teleology under the Kantian scholar Alois Riehl in 1892. In his unpublished memoirs, Tufts related a small episode regarding his experience in Germany that indicates the significance of this difference in attitudes toward religion. When he matriculated in Berlin, he was asked to state his religious affiliation, and he hesitated:

I didn't think "Congregationalist" would mean much in Deutschland. Fortunately a friendly German solved the difficulty by two questions and a syllogism. "Are you Jewish?" "No."

"Are you Roman Catholic?" "No." "Then you must be evangelical, for these are the only possibilities." ${ }^{4}$

Evangelical (meaning Lutheranist), however, was precisely what Tufts was not, and the Prussian public official's apparent lack of understanding of this can be taken as symptomatic of a wider lack of understanding on the part of Germany's scholars and the public at large (whose ideas were shaped by state religion) of the specific forms and denominations of Protestantism in the United States. The separation of church and state had not, in defiance of European fears, reduced the religiosity of Americans; on the contrary, it had strengthened it, as Reverend Robert Baird had already attempted to make clear to Europeans in $1844 .{ }^{5}$ The success of American Protestantism derived in part from the great distances separating communities in the United States - that is, from geographical conditions, which provided an ideal breeding ground for the English varieties of Calvinism (reformed) and their understanding of political-religious participation. These comparatively vast distances fortified the autarkic worldview of Calvinism, as it was initially developed in England against the background of the dominant episcopal Anglican church in the sixteenth and seventeenth centuries. These views stood in fundamental opposition to the practices in Lutheranist-dominated Germany. ${ }^{6}$

Tufts's memoirs are incomplete and were never published. Tufts himself has remained relatively unknown, and his writings are not generally included in the academic canon of the period from 1880 to 1930 that today is called the

3. James Hayden Tufts, "The Sources and Development of Kant's Teleology" (PhD diss., University of Chicago, 1892).

4. James Hayden Tufts, "Germany," n.d., James H. Tufts Papers, box 3, folder 13, University of Chicago Regenstein Library.

5. Robert Baird, Religion in America (New York: Harper and Bros., 1844).

6. It should be noted that at the beginning of the nineteenth century, some of the German states - including Prussia, Baden, Hessen, Nassau, and Pfalz — had a so-called united church, meaning that the Lutheran (evangelical) and Calvinist (reformed) churches were joined together. However, Lutheranism remained dominant even in these areas.

DANIEL TRÖHLER is Head of the Pestalozzianum Research Institute for the History of Education in the University of Applied Sciences at Teachers College, Zurich, Kurvenstrasse 17, Postfache, CH-8090 Zurich; e-mail <daniel.troehler@phzh.ch>. His primary areas of scholarship are the history and historiography of education, republicanism and education, pragmatism, and the internationalization of research. 
"progressive era." ${ }^{\prime 7}$ However, I do not refer to Tufts merely because his memoirs supply a fitting anecdote, nor do I think that the ideas of this little-noted thinker might fundamentally alter our understanding of American intellectual history. Nor is it my objective to extol Tufts as one of the "Greats" alongside the wellknown "Greats" - John Dewey, George Herbert Mead, William James, and Jane Addams.

In examining Tufts, my aim is, rather, to throw light on the tight net of mutual relations among those people who would later be celebrated as the stars of Pragmatism. Through this narrowly focused study, my goal is to achieve a kind of historical reconstruction of the mentality characterizing what William James called the "Chicago School" in a 1904 essay, published only twelve years after Tufts's return from Germany. ${ }^{8}$ Even in that essay, James had already carried out a reduction, narrowing down the Chicago School to John Dewey and his disciples. ${ }^{9}$ This reduction of the Chicago School to one man not only represents a pattern of thought common at that time; it also accords with the mainstream of traditional historiography up until today. Contemporary accounts of the intellectual development of individual persons frequently spring from pedagogical motives - namely, from the hope that the ideas or thoughts of a "hero" will aid us in the present. ${ }^{10}$

7. Tufts does not appear at all in the thirty-volume Encyclopedia Americana, for example, nor in Michael McGerr's recent book on this period, A Fierce Discontent: The Rise and Fall of the Progressive Movement in America, 1870-1920 (New York: Free Press, 2003). Tufts does not even figure in the canon of the so-called Pragmatists, which is generally restricted to Charles Sanders Peirce, William James, George Herbert Mead, and John Dewey (see, for instance, Israel Scheffler, Four Pragmatists: A Critical Introduction to Peirce, James, Mead, and Dewey [London: Routledge and Kegen Paul, 1974]). There are exceptions, of course: see James Campbell, The Community Reconstructs: The Meaning of Pragmatic Social Thought (Champaign: University of Illinois Press, 1992); James Campbell, ed., Selected Writings of James Hayden Tufts (Carbondale: Southern Illinois University Press, 1992); Andrew Feffer, The Chicago Pragmatists and American Progressivism (Ithaca: Cornell University Press, 1993); and John R. Shook, The Chicago School of Pragmatism, 4 vols. (Bristol: Thoemmes Press, 2000).

8. William James, "The Chicago School," Psychological Bulletin 1 (1904): 1-5.

9. Ibid. James characterized this group as follows: "Some universities have plenty of thought to show, but no school; others plenty of school, but no thought. The University of Chicago, by its Decennial Publications shows real thought and a real school. Professor John Dewey, and at least ten of his disciples, have collectively put into the world a statement, homogeneous in spite of so many cooperating minds, of a view of the world, both theoretical and practical, which is so simple, massive, and positive that, in spite of the fact that many parts of it yet need to be worked out, it deserves the title of a new system of philosophy" (p. 1).

10. This is the reason I do not consider here accounts such as Steven Rockefeller's impressive study, John Dewey: Religious Faith and Democratic Humanism (New York: Columbia University Press, 1991), or Bruce Kuklick's Churchmen and Philosophers: From Jonathan Edwards to John Dewey (New Haven and London: Yale University Press, 1985). Rockefeller takes a biographical approach and provides a study of arguments and concepts rather than an investigation of languages or mentalities. Furthermore, his study is pedagogically motivated. Rockefeller describes his goal as demonstrating the "relevance of Dewey's philosophy to the dilemmas of contemporary American society and the merging global community," and he maintains that Dewey's views continue to hold for "for all those throughout the world today who love freedom and seek to pursue the democratic way of life" (pp. 5, ix). The problems with Rockefeller's missionary tone are quite apparent in the current political context. Kuklick's study runs counter to my own analysis from a methodological perspective. My aim is to explore the mental dispositions and intellectual options that led to the development of a network of thought, while Kuklick, in asserting that "Dewey's arrival [at the University of Chicago] in 1894 created a 'school' of thought," seems to suggest that philosophical systems spring from individual thinkers. 
In contrast, the present study is an attempt at contextual reconstruction of a historical phenomenon: the "creation" of Chicago Pragmatism (which I take to include, among others, Mead, Tufts, and Addams, as well as Dewey). Such a project requires an analysis of the dominant mental dispositions that frame the theoretical options of these figures, as well as the personal networks out of which - against a background of specific social and economic developments - their discourse developed. Put more simply, no matter how the intellectual hierarchy of this "school" of Pragmatism is assessed, I argue, the exponents would most likely never have come together in Chicago without James Hayden Tufts. What interests me is the discourse underlying the invitations to Dewey and Mead in 1893 to join the faculty at the University of Chicago, as well as their connections with others outside the university (notably Jane Addams). I want to discover why we can speak of a "Chicago School" and what its shared mode of thinking was.

My thesis is that the common ground connecting what James called the Chicago School was American reformed Protestantism as it articulated itself within the unprecedented environment of a booming city like Chicago. In this context, American Protestantism is best understood not as a specific theology, but rather as a mentality, one that was highly skeptical toward universally applicable doctrines (see, for example, the Baptist and Congregational churches). Because these Protestant movements saw the local congregation as the fundamental and essential element of the church and were committed to the strong particularism of individual congregations, which were organized according to "democratic" structures, socialreligious practice was more important than theological speculations. Around the end of the nineteenth century, the liberal movements in American theology (such as "New Theology") strengthened the will toward worldly redemption. Therefore, this kind of Christianity does not - to use a distinction Reinhardt Koselleck made in one of his essays in Futures Past - refer to religiousness, as it can be found prior to the religious war in the seventeenth century; it should be understood instead as "secular" religion. ${ }^{11}$ In this spirit Theodore Munger observed in 1883: "The New Theology does indeed regard with question the line often drawn between the sacred and the secular... a line that, by its distinction, ignores the very process by which the kingdom of this world is becoming the kingdom of the Lord Jesus Christ.." ${ }^{12}$ Socialreligious movements that developed against the backdrop of massive urban problems, such as the Social Gospel, sought to reconcile Christianity and industrial society. ${ }^{13}$

I will develop my thesis, first, by showing how American Protestantism and democracy are connected in order to explain the narrow, religiously homogeneous

11. Reinhart Koselleck, Futures Past: On the Semantics of Historical Time (Cambridge: MIT Press, 1985).

12. Theodore T. Munger, cited in William R. Hutchinson, The Modernist Impulse in American Protestantism (Durham and London: Duke University Press 1992), 76. Munger, in his volume on Horace Bushnell, the prominent Congregationalist minister who rejected distinctions between the sciences and Christianity, constructed a prehistory of "New Theology." See Theodore T. Munger, Horace Bushnell: Preacher and Theologian (Boston and New York: Houghton, Mifflin, 1899).

13. It is not by chance that another Congregationalist minister, Washington Gladden, is held to have been the inaugurator of the Social Gospel. For a good overview, see Charles Howard Hopkins, The Rise of the Social Gospel in American Protestantism (New Haven: Yale University Press, 1940). 
personal network of Chicago Pragmatism. Then, I examine how American Protestantism reacted to the process of modernization. Through exploring this reaction and the specific efforts mounted to address problems associated with industrialization, we can reconstruct the ultimate aim of Protestantism (and, by extension, Pragmatism), which was to build the kingdom of God on earth. Finally, I describe how very modern Pragmatism seemed at that time, as it responded to the crisis of democracy with a demand for more democracy. Yet, I conclude, this vision of democracy, which so mistrusted modern institutions, was problematic.

\section{CALVINISM AND DemOCRACy}

Around the turn of the twentieth century, many reports from Germany sharply criticized both the American economic system of capitalism and its political system of democracy. In Germany, capitalism and democracy were lumped together and denounced (by Thomas Mann, for example) as incompatible with Christianity. ${ }^{14}$ This subjective and somewhat aggressive critique of the United States is really quite surprising given the fact that there was extensive discussion of Max Weber's theses in Germany at this time. Weber, of course, strongly argued for the Calvinist roots of the form of capitalism as performed in the eighteenth and nineteenth centuries.

Perhaps the quintessential model of a turn-of-the-century American capitalist, John D. Rockefeller, owner of the Standard Oil Company, was a deeply religious Baptist. The Baptists emerged in the early seventeenth century as a kind of left-wing splinter group within the Puritan movement. Their fundamentally democratic faith (with its principles of "soul competency" and religious liberty) distinguished the Baptists from other sects. According to their underlying conviction, only true believers, those who have personal faith in Christ, comprise the true church, and they confess their faith through baptism as adults. Regularly held readings of the Bible in the presence of the Holy Spirit are sufficient to uphold the true faith, on their view. This belief leads directly to the concept of congregational government and is related to the doctrine of "the priesthood of all believers." Only Christians, with a unified voice, should make the decisions in the church, and in this they contribute to establishing the kingdom of God on earth. By the late 1800s the Baptists had become the strongest Protestant community in the United States.

In a letter dated May 15, 1889, Rockefeller, certainly the wealthiest Baptist in America at that time, stated that he would contribute $\$ 600,000$ as a challenge pledge toward the first $\$ 1,000,000$ in endowment for a college to be established in Chicago. Rockefeller's donation was an act of philanthropy as practiced by a network of wealthy Americans of mostly Protestant origin. According to Weber's thesis, philanthropy could be understood as an effort by the wealthy in the face of the dark side of Protestant religiosity — harsh capitalism and its striving for political

14. Recently, critical studies on this German reaction have also appeared. See, for example, Georg Kamphausen, Die Erfindung Amerikas in der Kulturkritik der Generation von 1890 [The Invention of America in the Cultural Criticism of the Generation of 1890] (Weilerswist: Velbrück Wissenschaft, 2002); and Daniel Tröhler, "The Discourse of German 'Geisteswissenschaftliche Pädagogik' - A Contextual Reconstruction," Paedagogica Historica: International Journal of the History of Education 39, no. 6 (2003): 759-778. 
power - to put things right with God and their fellow human beings through acts meant to serve the social good, such as founding universities.

According to Dorothy Ross's analysis, the social sciences that emerged at these universities had a scientistic and liberal - or, as one would say in German, a social character, as they were grounded on the premise that American history was set on a millennial course, exempt from real historical change. ${ }^{15}$ In other words, the social sciences thrived in contexts that adopted the premise that America was the kingdom of God. Thus, it is not surprising that the introduction of the liberal arts, the secular humanities curriculum, at U.S. universities was in no way a departure from religious values but was instead seen as a more sublime form of transmitting those values. ${ }^{16}$

The idea of "American exceptionalism" was deeply rooted in the religious feelings of Americans, largely independent of social class. This is evident, for example, in the fact that in a large percentage of late-nineteenth-century American homes, The Pilgrim's Progress, John Bunyan's allegorical narrative about a "Christian" heading to salvation, occupied a place right next to the family Bible. ${ }^{17}$ The same vision is reflected in the distinctively American literature that emerged during the nineteenth century, including the work of authors such as Ralph Waldo Emerson, Henry David Thoreau, and especially Walt Whitman, whom Harold Bloom declared the center of the American canon of literature and poetry. ${ }^{18}$ In this work, America, democracy, and religion — not theology and also not denomination ${ }^{19}$ — are

15. Dorothy Ross, The Origins of American Social Science (Cambridge: Cambridge University Press, 1991). Compare this with Thomas L. Haskell, The Emergence of Professional Social Science: The American Social Science Association and the Nineteenth-Century Crisis of Authority (Urbana: University of Illinois Press, 1977).

16. Kersten Jacobson Biehn, "Kanonisierung der Freien Künste: Der Aufbau eines säkularen Lehrplans — das Beispiel der Princeton Universität" [Sanctifying the Liberal Arts: The Construction of a Secular Curriculumthe Example of Princeton University], Zeitschrift für Pädagogische Historiographie 10, no. 2 (2004): 74-82.

17. Bunyan wrote The Pilgrim's Progress while in prison from 1678 to 1684, during the period of the English Restoration. The book follows a Christian's arduous journey from his home to the heavenly city. In German Pietist circles, the book was read as an illustration of the inner journey upon which Christ had to embark; Americans saw the story as emblematic of their own task, to realize the kingdom of God in the United States. It is no coincidence that in John Steinbeck's The Grapes of Wrath, The Pilgrim's Progress was the only book besides the Bible that the Joad family possessed. David Tyack shows clearly that between 1860 and 1960 many American school superintendents patterned their autobiographies after Bunyan's description of life in The Pilgrim's Progress; in turn, this Protestant self-understanding and worldview exerted a strong influence on the field of education generally. See David Tyack, "Pilgrim's Progress: Toward a Social History of the School Superintendency, 1860-1960," History of Education Quarterly 16, no. 3 (1976): 257-300.

18. Harold Bloom, The Western Canon: The Books and School of the Ages (New York: Harcourt Brace, 1994), $264 \mathrm{ff}$.

19. It is important to see that theology is not what is at issue here - that is, we are not examining questions about the character of the Trinity or the doctrine of Holy Communion, for example. Instead, my interest lies in the mental dispositions that emerge from the practice of life and that limit intellectual options. Ultimately, I argue that people who are born into a Protestant Congregationalist community and are raised and socialized within that community have a different mentality than people brought up in, say, a Catholic milieu, particularly with regard to the issues of individual responsibility and political-democratic engagement. Given this background, Rockefeller's concern that Dewey did not become a member of a church in Chicago and did not send his children to Sunday school is less important; see Rockefeller, John Dewey, 214. Before the 1980s, there was virtually no research on American congregations in the area of intellectual history. At that time, the Congregational History Project was launched and it has since produced promising new research perspectives. See, for example, James P. Wind and James W. Lewis, eds., American Congregations, vol. 2 New Perspectives in the Study of Congregations (Chicago: University of Chicago Press, 1994). 
inseparable, as Whitman expressed in his 1871 work Democratic Vistas: "For I say at the core of democracy, finally, is the religious element. All the religions, old and new, are there. ${ }^{\prime 20}$ And in one of his later dedicatory poems, "Starting From Paumanok," Whitman wrote: "My comrade! For you to share with me two greatnesses, and a third one rising inclusive and more resplendent, The greatness of Love and Democracy, and the greatness of Religion. ${ }^{\prime 21}$

The influence that Whitman had on Dewey is evident in a letter that Dewey wrote to his wife, Alice Chipman Dewey, on April 16, 1887: "I have been reading Walt Whitman more and find that he has a pretty definite philosophy. His philosophy of democracy and its relation to religion strikes me as about the thing. ${ }^{\prime 22}$ Dewey's deep trust in Whitman continued throughout his life - it is an expression of the dominant discourse in the United States at the turn of the twentieth century that bound together the chief architects of Pragmatism.

\section{The Biographical Network of the Chicago School}

What we might today call the "moderate Protestant discourse" of that time the vision of establishing God's kingdom on earth - was infused by a religious understanding of social life and, in particular, an emphasis on mutual communication as a prerequisite of democratic decision making. This view was advocated in the academic milieu by a network of men who, as a rule, came from strict Protestant family backgrounds - mostly Congregationalists and also Baptists, but never Lutherans - and whose views were guided by their faith. Nor did these academics see a conflict between their commitments to religion and to liberal education: Frederic Henry Hedge, a Harvard professor and Unitarian pastor, for example, wrote, "The secularization of the College is no violation of its motto, 'Cristo et Ecclesiae.' For, as I interpret those sacred ideas, the cause of Christ and the Church is advanced by whatever liberalizes and enriches and enlarges the mind. ${ }^{\prime 23}$

Neither the "secularization" of the curriculum nor the increased emphasis on research at the universities changed the character of the firmly anchored Protestant self-understanding in the United States, despite the fact that the majority of immigrants in the late nineteenth century were no longer Protestants. The chronological priority of Puritanism, as well as its strong localism, which was particularly suited to meet the needs of such a vast country, discouraged the emergence of a serious competitor to "liberal Protestantism" in the public discourse. I will illuminate this point through the example of the University of Chicago, which

20. Walt Whitman, "Democratic Vistas," in Leaves of Grass and Selected Prose, ed. Ellmann Crasnow (1871; repr. London: Orion, 1993), 521.

21. Walt Whitman, "Starting from Paumanok," in Leaves of Grass (London: James R. Osgood and Company, 1881), 23.

22. John Dewey to Alice Chipman Dewey, April 16, 1887, The Correspondence of John Dewey, vol. 1, no. 00057 (Charlottesville, Virginia: InteLex Corporation, 2002).

23. Frederic Henry Hedge, cited in George M. Marsden, "The Soul of the American University: A Historical Overview," The Secularization of the Academy, eds. George M. Marsden and Bradley J. Longfield (New York and Oxford: Oxford University Press, 1992), 9. 
eventually replaced the old center of "New Theology," Andover Seminary, ${ }^{24}$ and thus became "probably the country's most powerful center of Protestant liberalism. ${ }^{\prime 25}$

In 1891, Rockefeller entrusted the president of the University of Chicago, Baptist theologian William Rainey Harper, with the great task of building up the university. Harper was looking for a star to head his philosophy department, and William James recommended Charles Peirce, but the appointment fell through when a member of the Harvard philosophy department expressed doubts as to Peirce's character. ${ }^{26}$ In the meantime, Harper hired James Hayden Tufts, one of his own former students from Yale Divinity School. At the time, Tufts had been working as an instructor in the University of Michigan philosophy department, headed by John Dewey. ${ }^{27}$ As noted previously, Harper offered the Chicago position on condition that Tufts first go to Germany to earn his doctorate in philosophy.

Tufts's departure left a hole in Dewey's philosophy department at Ann Arbor, which was to be filled by George Herbert Mead. Mead was the son of Congregationalist minister Hiram Mead, who had joined the faculty at the Oberlin Theological Seminary as professor of Sacred Rhetoric and Pastoral Theology in 1869. George Herbert Mead studied at Oberlin College, completing his bachelor's degree and forming a close friendship with Henry Northrup Castle, the son of a Protestant missionary in Hawaii. When Castle and his sister, Helen, traveled to Europe and settled temporarily in Leipzig, Germany, in 1888, Mead, too, went to Leipzig in order to pursue a $\mathrm{PhD}$ in philosophy and physiological psychology, where he studied mainly under Wilhelm Wundt. In 1891, Dewey's offer of an instructorship in philosophy and psychology at the University of Michigan interrupted Mead's work on his degree (interestingly, he never did complete his $\mathrm{PhD}$ ).

One year later in 1892, Tufts, now equipped with a German $\mathrm{PhD}$, became a member of the University of Chicago faculty. He urged Harper to invite Dewey to chair the philosophy department. Dewey accepted the post on the condition that Mead also be brought to Chicago as an assistant professor. Thus, in 1894, the Dewey-Mead-Tufts trio became the core of the group that William James would later call the Chicago School, a local and closely linked network of intellectuals whose understanding of themselves as academicians - in absolute contrast to the German tradition - was shaped by the idea that science and knowledge must have practical utility and must guide our living activity. Their shared Protestant social doctrine, as we will see, certainly informed their understanding of social issues. All of them became involved with the work of Jane Addams's settlement house, Hull House. This affinity with Addams was not surprising, since Addams, too, was

24. See Daniel Day Williams, The Andover Liberals: A Study in American Theology (New York: King's Crown Press, 1941).

25. Sydney E. Ahlstrom, A Religious History of the American People (New Haven and London: Yale University Press, 1972), 774-775.

26. Louis Menand, The Metaphysical Club (New York: Farrar, Strauss and Giroux, 2001), $285 \mathrm{ff}$.

27. John Dewey to James H. Tufts, June 20, 1889, The Correspondence of John Dewey, vol. 1, no. 11892. 
raised in a devout Protestant family, her father imparting to her strong sense of moral responsibility, purpose, and charity - traits characteristic of his Quaker faith. In addition, Tufts was an active member of the City Club of Chicago Committee on Housing Conditions for many years, even serving as chairman in 1910. Mead and Dewey were active in the League for Industrial Democracy, a social political movement founded in 1905 by Upton Sinclair and Jack London and aimed at the radical democratization of society (it was originally called the "Intercollegiate Socialist Society"). The ideal held up by Dewey and his colleagues was not the disinterested scholar but rather the socially responsible academician, and their primary object was not Bildung but rather social justice guided by a spirit of democratic Protestantism.

This network of colleagues, over time, formed even stronger professional and interpersonal relations. For instance, George and Helen Mead published Dewey's early progressive education papers under the title The School and the Society in 1900, and their only child, whom they named Henry Castle Albert Mead (after Helen's brother), later married Irene Tufts, the daughter of James Hayden Tufts and Cynthia Whitaker. When Dewey left Chicago for Columbia University in 1904, Tufts was promoted to professor and succeeded Dewey as chair of the philosophy department. In 1908, several years after Dewey had left, he and Tufts coauthored Ethics, and they published a completely revised edition in 1932. After Helen Mead's death, Dewey arranged for Mead's appointment as a professor at Columbia University for the 1931-1932 academic year; before he could take up that appointment, however, Mead died in Chicago on April 26, 1931.

\section{Calvinism and the Modern Age}

At the end of 1893, around the time that Dewey was hired by the University of Chicago, he wrote a letter to James Rowland Angell, the son of James Burrill Angell, a devout Congregationalist and president of the University of Michigan. The elder Angell had hired Dewey at Ann Arbor on the recommendation of George Sylvester Morris, while the younger Angell had studied under Dewey at Ann Arbor and was in Halle, Germany, when Dewey wrote him (he would later also come to Chicago and set up the new department of psychology there; in 1921 he became president of Yale University). In his letter, Dewey undertook to clarify the difference between German and American thinking. ${ }^{28}$ The Germans, Dewey wrote, had in the main developed an unsurpassed philological expertise, while at the same time building remarkable scientific laboratories. He doubted whether Americans could ever rival the Germans in the art of philology, but doubted also that efforts to do so would be justified, for it would not make sense according to the principle of the division of labor:

28. Unlike many other academics, Dewey had not studied in Germany. He was one of the first to obtain a doctorate in philosophy in the United States (from Johns Hopkins University). 
What we can do, perhaps, on the historical side is to interpret the history of thought more from the anthropological and political standpoint — as a social phenomenon.... I think that even the "Ideas" have yielded and turned out not "metaphysical" but aesthetic-political products. ${ }^{29}$

The separation of idealism and reality that characterized German thought was intellectually attractive to the Americans, as is indicated by their interest in and study of German philosophy. But such a dualistic starting point, premised as it was on the Lutheran doctrine of the two kingdoms, ${ }^{30}$ provided little tangible with which to understand and address the multitude of social, political, and economic problems at the turn of the century. ${ }^{31}$ Dewey, like many others, was seeking a "unified language," as he wrote in 1892 in a letter to Joseph Villiers Denney, professor of English and dean of the College of Arts, Philosophy, and Science at Ohio State University:

The "unified language" seems to be the most complete expression of what the "idea" does in thought, how religion has one language, philosophy another, science another, literature another $\&$ so on. Seeing the common objective fact, we get the unified language - the language of action. This is democracy - the appropriation of the store of spiritual wealth in all directions by the whole \& common people. Slang unifies with philosophy, theology \& poetry. This unified language is the breaking down of barriers \& rigid separation to my mind. ${ }^{32}$

This idea of an all-inclusive language, encompassing not only disciplinary and ideological thoughts but also thinking and acting, demonstrates just how far from liberal, in the current philosophical sense, these exponents who belonged to the "liberals" of the time actually were. The following assertion by Daniel Coit Gilman, founding president of Johns Hopkins University, illustrates this point: "American universities should be more than theistic; they may and should be avowedly Christian - not in a narrow or sectarian sense - but in the broad, open and inspiring sense of the Gospels. ${ }^{\prime \prime 3}$ These Protestant academics believed in teaching the

29. John Dewey to James Rowland Angell, May 10, 1893, The Correspondence of John Dewey, vol. 1, no. 00478.

30. Martin Luther and German evangelical Protestantism hold to the doctrine of the two kingdoms. In Christ's kingdom, governed by the spiritual authority of the Word and the Sacraments, there is grace and forgiveness of sins, and there are no differences among men. The other realm, the secular kingdom, is ruled by the temporal authority of the ruler, the sword, and the law; there is neither grace nor equality. Lutherans view the two kingdoms as instituted by God as mutually beneficial. The realm of Christ benefits from the temporal realm, because secular authority enforces peace in the world, and the temporal realm is served by the realm of Christ in its proclaiming of the Gospel through the Word. This Evangelical Protestantism holds further that it is of prime importance not to confuse the two kingdoms: God rules the spiritual kingdom through the Gospel. The Gospel is not meant to rule the secular kingdom, which is ruled by its own power and laws. Any attempt to use the Gospel to rule the secular world is an error. Politically, this doctrine - particularly since it was accompanied by a state church — was tantamount to total deprivation of people's right of decision making. This makes clear once more the fundamental difference between the Baptist faith and Congregationalism, and it explains why American Lutherans and Presbyterians did not follow the liberal turn of theology — that is, in the words of William R. Hutchinson, they were "most resistant to change." See William R. Hutchinson, The Modernist Impulse in American Protestantism (Durham and London: Duke University Press, 1992), 114.

31. These problems were primarily found in urban areas, such as Chicago. William Stead, son of a British Congregationalist minister, wrote an impressive account of the conditions in Chicago around 1893-1894; see William Thomas Stead, If Christ Came to Chicago! A Plea for the Union of All Who Love in the Service of All Who Suffer (Chicago: Laird and Lee, 1894).

32. John Dewey to Joseph Villiers Denney, February 8, 1892, The Correspondence of John Dewey, vol. 1, no. 00462 .

33. Gilman, cited in D.G. Hart, "Faith and Learning in the Age of the University: The Academic Ministry of Daniel Coit Gilman," in The Secularization of the Academy, eds. Marsden and Longfield, 107. 
Gospel - that is, the teaching of salvation through Jesus' words on the coming of the kingdom of God - but not with the intention of making those teachings the subject of discussion in theology or the science of religion. Instead, the teaching of salvation was seen as the prerequisite to thinking and acting, as the fertile ground, so to speak, on which life and thought took place and out of which sprung literature such as Walt Whitman's. The University of Chicago's President Harper provided another, more specific statement of this purpose when he told the student body that the fourth part of world history was beginning, it had its center in the United States, and in this era civilization was reaching its apex: according to him, "the history of civilization has been synchronous with the development of a pure and true conception of God, and of his relation to man" - that is, the BaptistProtestant interpretation of God and his relation to man. ${ }^{34}$ Harper saw this movement as a mandate for a mission that had been assigned to the United States by God and that had deep educational consequences: "If, now, our faith is sure that there has been committed to us this great mission, shall we not purify ourselves?" For Harper, this was a purification from both immorality and ignorance:

The ideal purification is a purification from vice and immorality, from sin of every kind and from impurity; but it is more - it is a purification (I use the word advisedly) from ignorance and prejudice, from narrowness of every kind, and from intellectual dishonesty. What is needed? The gospel and education. ${ }^{35}$

Only the two together would empower the United States to convert the world: "In this work of educating humanity to understand God and itself, America is the training-school for teachers. ${ }^{136}$

\section{The Kingdom of God on Earth}

American Protestantism, therefore, was a fundamental part of the American mentality during this period. This religious understanding was not fundamentalist in orientation but liberal in the American sense: mostly undogmatic, not specific to any denomination or church, and thus best understood as an all-encompassing certainty rather than as a sect. James B. Angell, Dewey's employer at the University of Michigan, characterized the proper relation of religion and higher education as follows:

Michigan is a Christian State, and her University can be true to her only by cherishing a broad unsectarian but earnest Christian spirit. I think that her sister universities in the Northwest are pervaded by the same spirit, and that they are contributing their full share to the dissemination of a Christian culture. ${ }^{37}$

Accordingly, true science could not oppose Christianity - in this circle, the choice was not one of either Darwinism or Christianity. To be liberal meant a lack of

34. William Rainey Harper, "America as a Missionary Field," in William Rainey Harper, Religion and the Higher Life (Chicago: University of Chicago Press, 1904), 175.

35. Ibid., 180-181 (emphasis added).

36. Ibid., 184.

37. James Burrill Angell, cited in Bradley J. Longfield, "From Evangelicalism to Liberalism: Public Midwestern Universities in Nineteenth-Century America," in The Secularization of the Academy, eds. Marsden and Longfield, 46. 
concern about dogmas, like original sin, and this opened up the possibility of thinking and acting in a scientific and modern way and, at the same time, in a Christian way. Of course, some theological tensions between these value systems were recognized, and numerous studies attempted to reconcile them. (See, for instance, the writings of John Fiske, who served under Tufts on the faculty of the University of Chicago's philosophy department. ${ }^{38}$ )

All of the participants in the Chicago School recognized that the conditions of living were changing, particularly in large cities such as Chicago. The goal of realizing the message of salvation required adjusting politics and education to these conditions in order to respond to them, where adjustment is an active process that requires targeted action. Out of this recognition grew the Social Gospel movement, to which Jane Addams also belonged. In Addams's programmatic treatise, "The Necessity for Social Settlements" (1892), written prior to the founding of the University of Chicago and nearly two years before Dewey and Mead's arrival in Chicago, she interpreted her settlement community, Hull House, as a response to the manifold social divisions characteristic of the urban experience, which had isolated people from one another and therefore weakened democracy, understood as "social intercourse. ${ }^{\prime 39}$ Addams saw democracy primarily as a process of social exchange, as a form of cooperation, to which she gave a religious interpretation:

\begin{abstract}
The Settlement movement is only one manifestation of that wider humanitarian movement which throughout Christendom, but pre-eminently in England, is endeavoring to embody itself, not in a sect, but in society itself....I believe that this turning, this renaissance of the early Christian humanitarianism, is going on in America, in Chicago, if you please, without leaders who write or philosophize, without much speaking, but with a bent to express in social service and in terms of action, the spirit of Christ. ${ }^{40}$
\end{abstract}

Action in the sense of self-activity stood at the center of intelligent cooperation for the purpose of mastering and changing the environment into an industrial democracy, and "activity" here was at its core religious.

This line of thinking was impressively developed by George Herbert Mead. As early as March 20, 1885, Mead wrote to his friend Henry Castle that Christianity was an infallible motive for an active life, "which raises every man to become a King and Priest, ${ }^{\star}$ me to God; makes every man a man of action and gives the most exceeding pleasure health and removes the dregs from the cup and despair from life. ${ }^{\prime 41}$ Mead developed this view shortly before he was asked to join the faculty at

38. Fiske's work in this area was controversial - at Harvard, he was condemned as an atheist and denied permission to teach. Tufts stood by him, however. In a 1916 letter, Tufts explicitly and positively identified Fiske as one of the few contemporary authors mentioned in Dewey's Democracy and Education. James Hayden Tufts to Edith Foster Flint, March 9, 1916, James H. Tufts Papers, box 1, folder 7, University of Chicago Regenstein Library. See also John Dewey, Democracy and Education (1916; repr. New York: Free Press 1944), 45n.

39. Jane Addams, "The Subjective Necessity for Social Settlements," in Philanthropy and Social Progress, ed. Henry C. Adams (New York: Thomas Y. Cromwell, 1893), 1.

40. Ibid., 19-20 (emphasis in original).

41. George Herbert Mead to Henry Northrup Castrup, March 20, 1885, Mead Papers, box 1, folder 2, University of Chicago Regenstein Library (emphasis in original; asterisk indicates uncertain reading of Mead's handwriting). 
the University of Chicago on Dewey's recommendation. Evidence of this development is a forty-page manuscript, probably written in 1893 while Mead was still in Ann Arbor. In this lecture, Mead discussed the meaning of the New Testament, focusing on the relationship of Jesus Christ to John the Baptist and on Christ's Gospel, specifically on his announcement of the coming kingdom of God on earth in the Sermon on the Mount. According to Mead, it is from their spontaneous relationship with God in prayer that men recognize they have common - not contradictory - interests, which are endangered by the capitalist economy: "The centering of our interest upon riches that pass away involves the absence of all 'treasure in the Kingdom of Heaven.' For where your treasure is there will your heart be also [Matthew 6:21]." Mead continued, "We find in a later chapter [of the Holy Bible] still more strongly expressed the destructive effect of the greed for wealth upon that identity of interest that should exist between all men in the Kingdom, - 'If thou wilt to be perfect go and sell all that thou hast and give to the poor and thou shalt have treasure in heaven' [Matthew 19:21]. ${ }^{\prime 42}$ Mead then quoted Matthew 19:24 - the passage saying that it is easier for the camel to pass through a needle than it is for a rich man to enter Heaven - to which he offered the following as a complement:

It is just as impossible to do both - serve God in this Kingdom and Mammon as well. One's life is not made up of the abundance of things one possesses, but life is more than meat. In God's Kingdom it is impossible that one's interest should be centered upon the mere conditions of existence. ${ }^{43}$

Faith in Christ and thus the "community of interest" of men is not a matter of rational understanding, but it is also not a matter of "emotion in the sense in which we generally perhaps consider an emotion. It does not represent a feeling insofar as this is something static but a state mind prepared for the most absolute, the most perfect acting — it is the condition of perfect activity. ${ }^{\prime 44}$ To provide evidence for this interpretation of the Sermon on the Mount, Mead referred to William James's Principles in Psychology, first published in 1890, in which James insisted that emotions are the consequence of activities and thus exist prior to all attempts at rationalization. In that work, James had wanted to demonstrate clearly that the traditional assumption of a causal relation of the following type was false: coming unexpectedly upon a bear in the woods, then experiencing fear, then running away. James wrote that it was more correct to assume that we experience fear because we run away - that running away is the physical activity and that the subsequent perception of the activity is what we call a feeling. ${ }^{45}$

Following this digression, Mead returned to Jesus in order to show that the emotion of love can arise only in connection with action and activity:

I come back to our theme if the principle which Jesus represents is to be expressed as an emotion. The emotion of love - it can only be as an active principle - the principle of the most

42. George Herbert Mead, untitled essay on Jesus, love, activity [ca. 1893], Mead Papers, box 10, folder 1, University of Chicago Regenstein Library: 20-21.

43. Ibid., 21.

44. Ibid., 26.

45. William James, Principles in Psychology (New York: Henry Holt, 1890), 449-450. 
complete and absolute activity our natures are capable of. It must have back of it the instinctive actions of the whole social - in other words: religious - nature and it must have the power of supporting these activities at once and without cessation. ${ }^{46}$

Or, as Dewey expressed it in the same year of 1893:

Christianity is revelation, and revelation means effective discovery, the actual ascertaining or guaranteeing to man of the truth of his life and the reality of the Universe. It is at this point that the significance of democracy appears. The kingdom of God, as Christ said, is within us, or among us. ${ }^{47}$

\section{DEMOCRACY AS REDEMPTION}

The idea of a true community of interests and thus the realization of the kingdom of God on earth was not held exclusively by the Chicago Pragmatists; rather, it shaped a wider Protestant discourse that dominated the field of common schooling at the end of the nineteenth century. ${ }^{48}$ This same idea can be seen in Graham Taylor, who, after Jane Addams, was perhaps the most important exponent of the settlement house. Like Addams and others in the Chicago School, Taylor oscillated between scholarship and social engagement: he was founder and director of the Chicago Commons Settlement House and, at the same time, a professor of biblical sociology in the sociology department at the Chicago Theological Seminary. ${ }^{49}$ His lectures were based largely on Francis Herbert Stead's The Kingdom of God: A Plan of Study in Three Parts, which was written in 1893. However - and this may explain why the Dewey circle had close contacts with Addams but not with Taylor Taylor championed a type of social reform that was much more closely oriented to formal institutions: for example, it targeted, among other things, better conditions for, and an increase in, civic participation and voting among the work force.

In 1882, about ten years before Mead set down his thoughts about the Sermon on the Mount as a guide for realizing the kingdom of God on earth, Taylor delivered a Thanksgiving address titled, "The Unity of Human Interests." While the address has been passed down to us only in the form of phrases and abbreviated words ("That in Ch[rist] of G[od] at call of State, on day sacred to Home"), its content is illuminating. In contrast to Mead or Addams, Taylor asserted that the institutionalized interests of state, church, and family "are really one. Their common blessings imply substantial unity." ${ }^{\prime 50}$ This was precisely not what Mead, Dewey, and Addams thought. Whereas they shared with Taylor the vision of a kingdom of

46. Mead, untitled essay on Jesus, love, activity, 37f. (punctuation as in original).

47. John Dewey, "Christianity and Democracy" (1893), in John Dewey: The Early Works, 1893-1894, vol. 4, ed. Jo Ann Boydston (Carbondale: Southern Illinois University Press, 1971), 6-7.

48. David Tyack, "The Kingdom of God and the Common School: Protestant Ministers and the Educational Awakening in the West," Harvard Educational Review 36, no. 4 (1966): 447-469.

49. Taylor's private papers contain the following description of his settlement house: "Chicago Commons is a 'Social Settlement' located at the corner of Grand Avenue and Morgan Street. It was founded in May, 1894, and is the home of a group of people who want to share the life of the neighborhood its comforts and discomforts; its privileges and responsibilities; its political, civic and personal duties and pleasures. They offer their home as a social center for the neighborhood, in which they desire to be friends, fellow-citizens, neighbors," Graham Taylor Papers, Chicago Commons Scrapbooks, box 1 (1900-1906), Newberry Library, Chicago.

50. Graham Taylor, "The Unity of Human Interests - Address at Thanksgiving" [November 30, 1882], Graham Taylor Papers, Newberry Library, Chicago. 
God and the idea of a community of interests, they did not view these primarily in the context of formal institutions, and certainly not the church. It is not by chance that Jane Addams was convinced that Hull House was the expression of a renaissance of early Christianity. Mead, Dewey, and Addams were less concerned than Taylor with strengthening the institutional power of the state and were not at all interested in a strong church; instead, they sought to perfect their vision of community as an expression of a common interest that was Christian, social, and democratic - and therefore critical for American development. They viewed as "good" that which emerged from unity and remained unified; "bad" was the particular or the particularizing: "The bad act is partial, the good organic.... The good man, in a word, is his whole self in each of his acts; the bad man is a partial (and hence a different) self in his conduct. He is not one person, for he has no unifying principle. ${ }^{\prime 51}$ Within this framework, capitalism had to be criticized, not because it is based on private ownership of the means of production, but instead because of its socially divisive, segregating consequences, which, because it made common intercourse, the community of interests, and organic unity impossible, stood in the way of realizing the kingdom of God on earth.

Theologian and journalist George Davis Herron, one of the most popular activists of the Social Gospel movement, expressed this by calling America undemocratic:

We Americans are not a democratic people. We do not select the representatives we elect; we do not make our own laws; we do not govern ourselves. Our political parties are controlled by private, close political corporations that exist as parasites upon the body politic, giving us the most corrupting and humiliating despotisms in political history, and tending to destroy all political faith in righteousness. ${ }^{52}$

This critique, formulated in the language of republicanism, finds fertile ground in the Protestant ideal of liberal reform, according to which social, religious, and democratic life are fundamentally identical - a natural expression of the common interests of men. On this view, formal institutions become, if not superfluous, certainly secondary:

The political realization [of Christianity] will be a pure democracy. Christianity can realize itself in a social order only through democracy, and democracy can realize itself only through the social forces of Christianity. A pure social democracy is the political fulfillment of Christianity;...It is the historical and providential idea that God shall lead the people by his Spirit of right as his sons, governing them inspirationally rather than institutionally. ${ }^{53}$

51. John Dewey, "The Study of Ethics: A Syllabus," in John Dewey: The Early Works, vol. 4, ed. Boydston, 245.

52. George Davis Herron, "The Christian State - The Social Realization of Democracy," in The Christian State: A Political Vision of Christ (New York: Thomas Y. Crowell, 1895), 76-77. Herron was a Congregational Church minister and professor of applied Christianity at Grinnell College from 1893 to 1899 . In many ways, his views were closer to those of Graham Taylor. In fact, Taylor invited him to teach "social religion" at the Chicago Commons School of Social Economics in 189 (see Graham Taylor Papers, Chicago Commons Scrapbooks, box 2, Newberry Library, Chicago). After his scandalous divorce in 1899, Herron resigned from Grinnell College and joined the Socialist Party. The passage cited here, which is as representative of Pragmatism as it is of Christian Socialism, shows how closely connected the various social reform movements were; specifically, it indicates that the mentality of liberal Protestantism linked these movements together.

53. Ibid., 74-75. 
This argument is not very far from the analysis that Dewey set forth in The Public and Its Problems, first published in 1927, when he accused the captains of industry of destroying democracy in order to serve their private interests. ${ }^{54}$ In this connection, Dewey said, "the cure for the ailments of democracy is more democracy," so that a scattered and mobile and diverse public can come to "recognize itself as to define and express its interests." Given this premise, it is not surprising that Dewey viewed democracy as the "idea of community life itself," in which there is a single consciousness of a single interest that produces the public as a public and in this way makes democracy truly possible in the first place: "The clear consciousness of a communal life, in all its implications, constitutes the idea of democracy.. ${ }^{\prime \prime 5}$ As Dewey repeatedly stressed, the vitality of democratic social life does not depend on formal democratic institutions, like voting or representative government, but vice versa.

Thirty years after the period examined here, Dewey's mode of thinking had not essentially changed: "Democracy will come into its own, for democracy is a name for a life of free and enriching communion. It had its seer in Walt Whitman. It will have its consummation when free social inquiry is indissolubly wedded to the art of full and moving communication. ${ }^{\prime 56}$ On Dewey's view, the project of communion and immediacy must start with education, namely, education in the home within communal "face-to-face relationships." ${ }^{157}$

Upon this background, it is probably advisable when interpreting My Pedagogic Creed - Dewey's first work on education to enjoy broad reception - to

54. John Dewey, The Public and Its Problems (1927; repr. Athens: Ohio University Press, 1954). This book is an answer to Walter Lippman's The Phantom Public (1925; repr. New York: Harcourt, Brace, 1929). Lippmann, the son of second-generation German-Jewish parents, declared himself a socialist during his years at Harvard, but, starting at the turn of the twentieth century, he turned to radical liberalism in the European sense. In The Phantom Public, Lippmann criticized the Protestant-republican ideology of homo politicus: "The environment is complex. Man's political capacity is simple" (p. 78). He wrote that the ideal of the old American communities, whereby "the voter's opinions were formed and corrected by talk with their neighbors," was no longer effective within the complexity of the "Great Society" (p. 181). For this reason, Lippmann called for a plural public, arising from the exchange of interests: "I have conceived public opinion to be, not the voice of God, nor the voice of society, but the voice of the interested spectators of action" (p. 197). Dewey responded first with a critical review (see John Dewey, "Practical Democracy," New Republic 45 [December 2, 1925]: 52-54) and then with a series of lectures at Kenyon College, Ohio, in 1926. These lectures were later edited and published as The Public and Its Problems.

55. Dewey, The Public and Its Problems, 140, 148-149 (emphasis in original).

56. Ibid., 184.

57. Ibid., 218. Evidently, The Public and Its Problems was not the definitive answer, because Dewey was unable to solve the problem of how local communities, which he wished to revitalize, could be brought to engage in the type of global communication necessary to advance scientific knowledge. That is, he failed to resolve the issue of why local communities should want to harmonize with other communities. Dewey developed a strategy for harmonizing the particular with the universal in his 1934 book, A Common Faith. What is crucial in the present context is not so much the fact that in this work Dewey, as Rockefeller stresses, once again uses the term "God" in a positive sense after not having done so many years (see Rockefeller, John Dewey, 234), but rather the fact that human and religious experience are made synonymous - that is, plurality is attributed to an assumed unity. Compare with Daniel Tröhler, "The Global Community, Religion, and Education: The Modernity of Dewey's Social Philosophy," Studies in Philosophy and Education 19, no. 1-2 (2000): 159-186. 
understand the democratic element of his theory of the school in the context of Dewey's own summary of his educational belief: "I believe that in this way the teacher always is the prophet of the true God and the usherer in of the true kingdom of God..$^{\prime \prime 58}$ In these days when religion in education is invariably equated with the agenda of conservative, fundamentalist Christianity, it is important to consider, by way of contrast, an encompassing religious stance on education that does not lie in an illiberal religiousness.

58. John Dewey, "My Pedagogic Creed" (1897), in John Dewey: The Early Works, 1895-1898, vol. 5, ed. Jo Ann Boydston (Carbondale: Southern Illinois University Press, 1972), 95. See also Dewey's final address before the Students' Christian Association of the University of Michigan on May 27, 1894: "The responsibility now upon us is to form our faith in the light of the most searching methods and known facts; it is to form that faith so that it shall be an efficient and present help to us in action, in the co-operative union with all men who are sincerely striving to help on the Kingdom of God on earth" (John Dewey, "Reconstruction" [1894] in John Dewey: The Early Works, vol. 4, ed. Boydston, 105).

AN EARLIER VERSION OF THIS PAPER was presented at the International Research Seminar "Pedagogical Modernization: Secular and Religious Aspects of Pedagogics," Ascona, Switzerland, October 2004; at the University of Wisconsin, Madison, 2005; and at Rice University, Houston, Texas, 2005. I would like to thank Thomas S. Popkewitz, Thomas L. Haskell, and the editor of Educational Theory, Nicholas C. Burbules, for their amicable help in shaping this article. 